Dept. of Food Hygiene,

Fac. Vet. Med., Kafrelsheikh Univ.

\title{
INCIDENCE OF AEROBIC SPOREFORMERS IN UHT MILK
}

(With 4 Tables and 3 Figures)

By

AZZA M.K. SOBEIH

(Received at 3/8/2009)

\section{مدى تواجد الميكروبات المتحوصلة الهوائية في اللبن المعقم

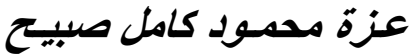

أجرى هذا البحث علي سبعون عينة عشو ائية من اللبن المعقم (منها 25 عبنة عينة لبن طبيعي كامل

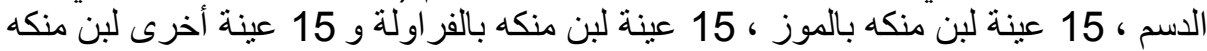

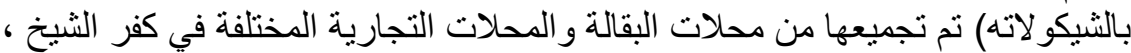

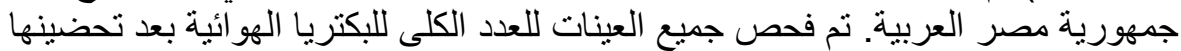

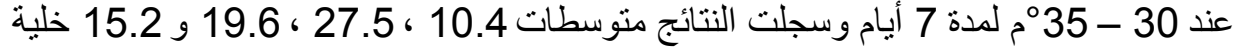

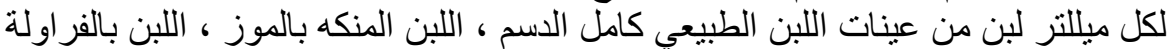

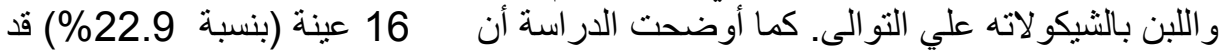

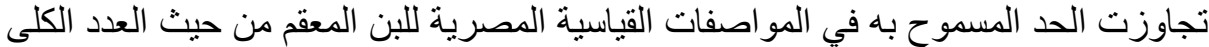

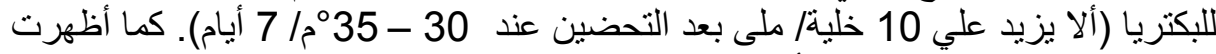

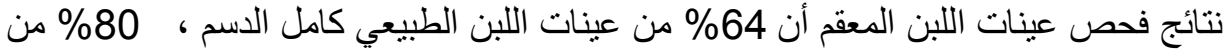

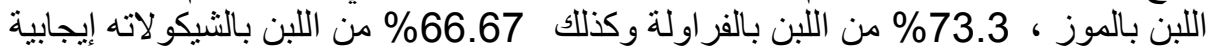
للبكتريا الهو ائية المتحوصلة (الباسيلس) بمتوسط عددي

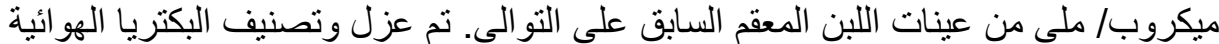

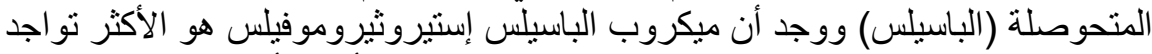

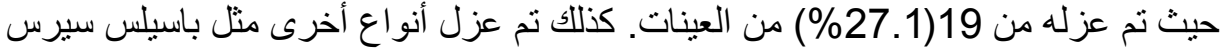

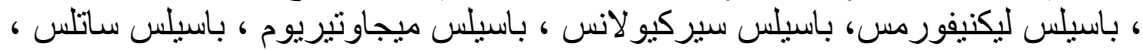

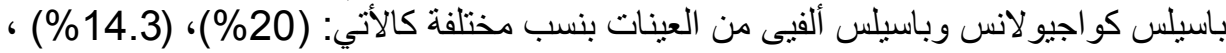

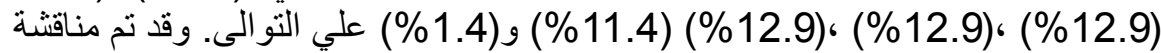

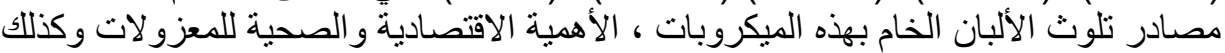

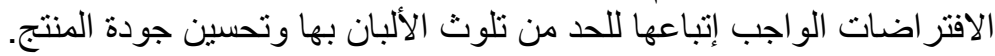

\section{SUMMARY}

Seventy (25 unflavored full cream, 15 banana flavored, 15 strawberry flavored and 15 chocolate flavored) UHT milk samples were collected randomly from different groceries and supermarkets in Kafrelsheikh, Egypt. All samples were examined for aerobic plate count and aerobic 
sporeformers. Results revealed that the mean aerobic plate count for unflavored full cream, banana flavored, strawberry and chocolate flavored UHT milk samples examined (after incubation of samples at $30-35^{\circ} \mathrm{C} / 7$ days $)$ were $10.4 \pm 9.6,27.5 \pm 39.4,19.6 \pm 27.9$ and $15.2 \pm 26.6$ $\mathrm{cfu} / \mathrm{ml}$ respectively. Results declared that 16 (22.9\%) out of 70 UHT milk samples examined, exceeded the Egyptian standards of total aerobic bacterial count $(10 \mathrm{cfu} / \mathrm{ml})$ for long life sterilized milk. Statistical analytical results of aerobic sporeformers count revealed that $16(64 \%)$ of unflavored full cream, $12(80 \%)$ of banana flavored, $11(73.3 \%)$ of strawberry flavored and $10(66.67 \%)$ of chocolate flavored UHT milk samples were positive for aerobic sporeformers with mean counts of $13.19 \pm 28.7,28.67 \pm 44.1,7.27 \pm 4.3$ and $7.70 \pm 4.6 \mathrm{cfu} / \mathrm{ml}$ respectively. The isolated bacillus species were identified as B. stearothermophilus which recorded the highest incidence that it could be detected in $19(27.1 \%)$ of the examined samples, followed by B. cereus, B. Licheniforms, B. circulans, B. megaterium , B. subtilis, B. coagulans and $B$. alvei that could be isolated from 14(20\%), 10 (14.3\%), 9(12.9\%), 9(12.9\%), 9(12.9\%), $8(11.4 \%)$ and $1(1.4 \%)$ of the examined samples respectively. Source of these bacteria in milk, their economic and public health importance as well as the suggestive measures for control were discussed. This study was planned to throw light on aerobic plate count and the incidence of aerobic sporeformers in the examined UHT milk samples regarding the Egyptian Standards.

Key words: UHT milk-APC-Aerobic sporformers - Bacillus Species

\section{INTRODUCTION}

Ultra-heat treated (UHT) milk was developed to meet the demand for milk be stable for extended periods at room temperature. UHT was defined by Dr. Harold Burton- Pioneer of UHT milk processing as a treatment in which milk is heated to a temperature of $135-150{ }^{\circ} \mathrm{C}$ in continuous flow in a heat exchanger for sufficient length of time (1-4 S) to achieve commercial sterility with an acceptable amount of change in the product (Varnam and Sutherland, 1994). In spite of this treatment, UHT milk was accounted for $1.5 \%$ of 69 outbreaks due to milk and dairy products as reported by De Buyser et al. (2001). Also, Hammer et al. (1995) recorded that heat resistant mesophilic aerobic sporformers have been detected in UHT milk in several European countries since 1985. 
Members of genus bacillus such as B. licheniformis, B. cereus, B. subtilis, B. stearothermophilus, B. polymyxa, B.badius, B. coagulans, $B$. mycoides and $B$. pumilus are the most important spoilage species isolated from UHT milk by many authors (Foschino et al., 1990; Hasan, 1990; Aly, 1992; El-Shennawi et al., 1995; Ezz-El-Din, 1999 and Taher, 2004). These bacteria contaminate milk supplies from water, udder and teat surfaces or from feed concentrate, dust, soil, milk stone deposits on farm tanks, pumps, pipelines and processing equipment and their endospores can survive UHT treatment (Meer et al., 1991; Aman et al.,1998; Huang et al., 1999; Scheldeman et al., 2002). Post processing contamination due to failure in equipment sterilization downstream thermal processing or most commonly during packaging was also recorded (Varnam and Sutherland, 1994).

Bacillus spp. are associated with flavor defects as fruity, sour, bitter, unclean also sweet curdling and bitty cream which caused by the action of proteolytic, lipolytic and phospholipase enzymes. Although the main concern about the presence of Bacillus spp. in milk is off-flavor production with consequent reduction of shelf life, it also represents a public health hazard. B. cereus food poisoning is a major concern world wide and it is responsible for two forms of human gastroenteritis, but the number of cells required for toxin production is high, $10^{6}$ to $10^{7} / \mathrm{ml}$ (Ombui et al., 2008; Meer et al., 1991; Rangasamy et al., 1993).

There are several reasons for the problems of spore forming bacteria in the dairy industry. First of all, it is impossible to completely avoid their presence in milk. Secondly their spores are very hydrophobic and will attach to surfaces of the pipelines of the dairy plant where they might multiply and will re-sporulate. A third problem is that spores are heat resistant (Andersson et al., 1995). Therefore this work was planned to throw light on the incidence of aerobic sporeformers in UHT milk.

\section{MATERIALS and METHODS}

\section{Samples:}

Seventy random samples of market UHT milk were collected randomly from different groceries and supermarkets in Kafr El-Sheikh, Egypt. Twenty five samples were unflavored full cream UHT milk and forty five were flavored UHT milk (chocolate, banana and strawberry, 15 samples each). All samples were rapidly delivered to the laboratory, prepared and serially diluted according to A.P.H.A. (1992).

UHT milk samples were divided into to parts, first part was incubated at $30-35^{\circ} \mathrm{C}$ for seven days then examined for: 


\section{Aerobic plate count:}

According the technique recommended by A.P.H.A. (1992). The second part of the samples was serially diluted and examined for:

\section{Aerobic sporeformers count:}

The already prepared serial dilutions and the original samples were heated at $80^{\circ} \mathrm{C} / 10$ minutes to destruct all vegetative cells then cooled to $10^{\circ} \mathrm{C}$. One milliliter quantities from each dilution as well as original samples were plated in sterile duplicate pertri dishes using dextrose tryptone agar (Oxoid, 1980) and polymyxin pyruvate egg yolk manitol bromothymol blue agar (PEMBA) (Holbrook and Anderson, 1980). Following incubation at $32^{\circ} \mathrm{C}$ for $72 \mathrm{~h}$ and $30^{\circ} \mathrm{C}$ for $48 \mathrm{~h}$ respectively, the total number of colonies were calculated and recorded. Separate colonies of acid producing (yellow halo) and non acid producing were picked up and purified on nutrient slants for further identification.

\section{Identification of isolated Bacillus species:}

Isolated colonies were confirmed by microscopic examination and biochemically according to Krieg and Holt (1984).

\section{RESULTS}

Table 1: Statistical analytical results of aerobic plate count in the examined UHT milk samples (after incubation of samples at $30-35^{\circ} \mathrm{C} / 7$ days)

\begin{tabular}{|l|c|c|c|c|c|c|c|c|}
\hline \multirow{2}{*}{ UHT milk samples } & \multirow{2}{*}{$\begin{array}{c}\text { No. of the } \\
\text { examined } \\
\text { samples }\end{array}$} & \multicolumn{2}{|c|}{$\begin{array}{c}\text { Positive } \\
\text { samples }\end{array}$} & \multicolumn{4}{c|}{ APC ( cfu/ml) } & \multicolumn{2}{c|}{$\begin{array}{c}\text { Samples } \\
\text { exceeding } \\
\text { *E.S. }\end{array}$} \\
\cline { 3 - 10 } & & No. & $\%$ & Min. & Max. & Mean \pm SD & No. & $\%$ \\
\hline Unflavored full cream & 25 & 20 & 80 & 4 & 39 & $10.4 \pm 9.6$ & 6 & 24 \\
\hline Banana flavored & 15 & 8 & 53.3 & 3 & 100 & $27.5 \pm 39 . .4$ & 3 & 20 \\
\hline Strawberry flavored & 15 & 10 & 66.67 & 2 & 90 & $19.6 \pm 27.9$ & 3 & 20 \\
\hline Chocolate flavored & 15 & 10 & 66.67 & 2 & 50 & $15.2 \pm 26.6$ & 4 & 26.7 \\
\hline Total & 70 & 48 & 68.57 & 2 & 100 & $16.67 \pm 22.6$ & 16 & 22.9 \\
\hline
\end{tabular}

* Egyptian standards (2005)

Table 2: Statistical analytical results of aerobic sporeformers count in the examined UHT milk samples

\begin{tabular}{|l|l|l|l} 
UHT milk samples & No. of the & Positive & Aerobic sporeformers count
\end{tabular}


Assiut Vet. Med. J. Vol. 55 No. 123 October 2009

\begin{tabular}{|l|c|c|c|c|c|c|}
\hline & examined & \multicolumn{2}{|c|}{ samples } & \multicolumn{3}{c|}{ (cfu/ml) } \\
\cline { 3 - 7 } & samples & No. & $\%$ & Min. & Max. & Mean \pm SD \\
\hline Unflavored full cream & 25 & 16 & 64 & 3 & 120 & $13.19 \pm 28.7$ \\
\hline Banana flavored & 15 & 12 & 80 & 4 & 140 & $28.67 \pm 44.1$ \\
\hline Strawberry flavored & 15 & 11 & 73.3 & 3 & 16 & $7.27 \pm 4.3$ \\
\hline Chocolate flavored & 15 & 10 & 66.67 & 1 & 14 & $7.70 \pm 4.6$ \\
\hline Total & 70 & 49 & 70 & 1 & 140 & $14.53 \pm 27.96$ \\
\hline
\end{tabular}

Table 3: Frequency distribution of positive UHT milk samples according to aerobic sporeformers count

\begin{tabular}{|c|c|c|c|c|c|c|}
\hline \multirow{2}{*}{$\begin{array}{c}\text { Aerobic } \\
\text { sporeformers } \\
\text { count (cfu/ml) }\end{array}$} & $\begin{array}{c}\text { Unflavored } \\
\text { Full cream } \\
\text { positive UHT } \\
\text { milk samples }\end{array}$ & \multicolumn{3}{|c|}{$\begin{array}{c}\text { flavored positive UHT milk } \\
\text { samples }\end{array}$} & \multicolumn{2}{c|}{ Total } \\
\cline { 3 - 7 } & & Banana & Strawberry & Chocolate & No. & $\% *$ \\
\hline$<10$ & 12 & 4 & 7 & 6 & 29 & 59.19 \\
\hline $10:<20$ & 3 & 5 & 4 & 4 & 16 & 32.65 \\
\hline $20:<40$ & 0 & 1 & 0 & 0 & 1 & 2.04 \\
\hline $40:<80$ & 0 & 0 & 0 & 0 & 0 & 0 \\
\hline $80: \leq 100$ & 0 & 1 & 0 & 0 & 1 & 2.04 \\
\hline$>100$ & 1 & 1 & 0 & 0 & 2 & 4.08 \\
\hline
\end{tabular}

* Percentages were calculated to the number of positive samples $(n=49)$

Table 4: Statistical analytical results of the identified Bacillus species isolated from the examined UHT milk samples

\begin{tabular}{|c|c|c|c|c|c|c|c|c|c|c|}
\hline \multirow{3}{*}{$\begin{array}{l}\text { Identified Bacillus } \\
\text { species }\end{array}$} & \multicolumn{10}{|c|}{ Positive UHT milk samples } \\
\hline & \multicolumn{2}{|c|}{$\begin{array}{l}\text { Unflavored } \\
\text { full cream } \\
(\mathrm{n}=25)\end{array}$} & \multicolumn{2}{|c|}{$\begin{array}{c}\text { Banana } \\
\text { flavored } \\
(\mathrm{n}=15)\end{array}$} & \multicolumn{2}{|c|}{$\begin{array}{c}\begin{array}{c}\text { Strawberry } \\
\text { flavored } \\
(\mathrm{n}=15)\end{array} \\
\end{array}$} & \multicolumn{2}{|c|}{$\begin{array}{c}\text { Chocolate } \\
\text { flavored } \\
(\mathrm{n}=15)\end{array}$} & \multicolumn{2}{|c|}{$\begin{array}{c}\text { Total } \\
(\mathrm{n}=70)\end{array}$} \\
\hline & No. & $\%$ & No. & $\%$ & No. & $\%$ & No. & $\%$ & No. & $\%$ \\
\hline B. stearothermophilus & 5 & 20 & 4 & 26.7 & 7 & 46.7 & 3 & 20 & 19 & 27.1 \\
\hline B. cereus & 3 & 12 & 5 & 33.3 & 5 & 33.3 & 1 & 6.7 & 14 & 20 \\
\hline B. Licheniformis & 4 & 16 & 2 & 13.3 & 3 & 20 & 1 & 6.7 & 10 & 14.3 \\
\hline B. circulans & 3 & 12 & 4 & 26.7 & 1 & 6.7 & 1 & 6.7 & 9 & 12.9 \\
\hline B. megaterium & 4 & 16 & 1 & 6.7 & 1 & 6.7 & 3 & 20 & 9 & 12.9 \\
\hline B. subtilis & 3 & 12 & 2 & 13.3 & 1 & 6.7 & 3 & 20 & 9 & 12.9 \\
\hline B. coagulans & 2 & 8 & 3 & 20 & 1 & 6.7 & 2 & 13.3 & 8 & 11.4 \\
\hline B. alvei & 0 & 0 & 1 & 6.7 & 0 & 0 & 0 & 0 & 1 & 1.4 \\
\hline
\end{tabular}




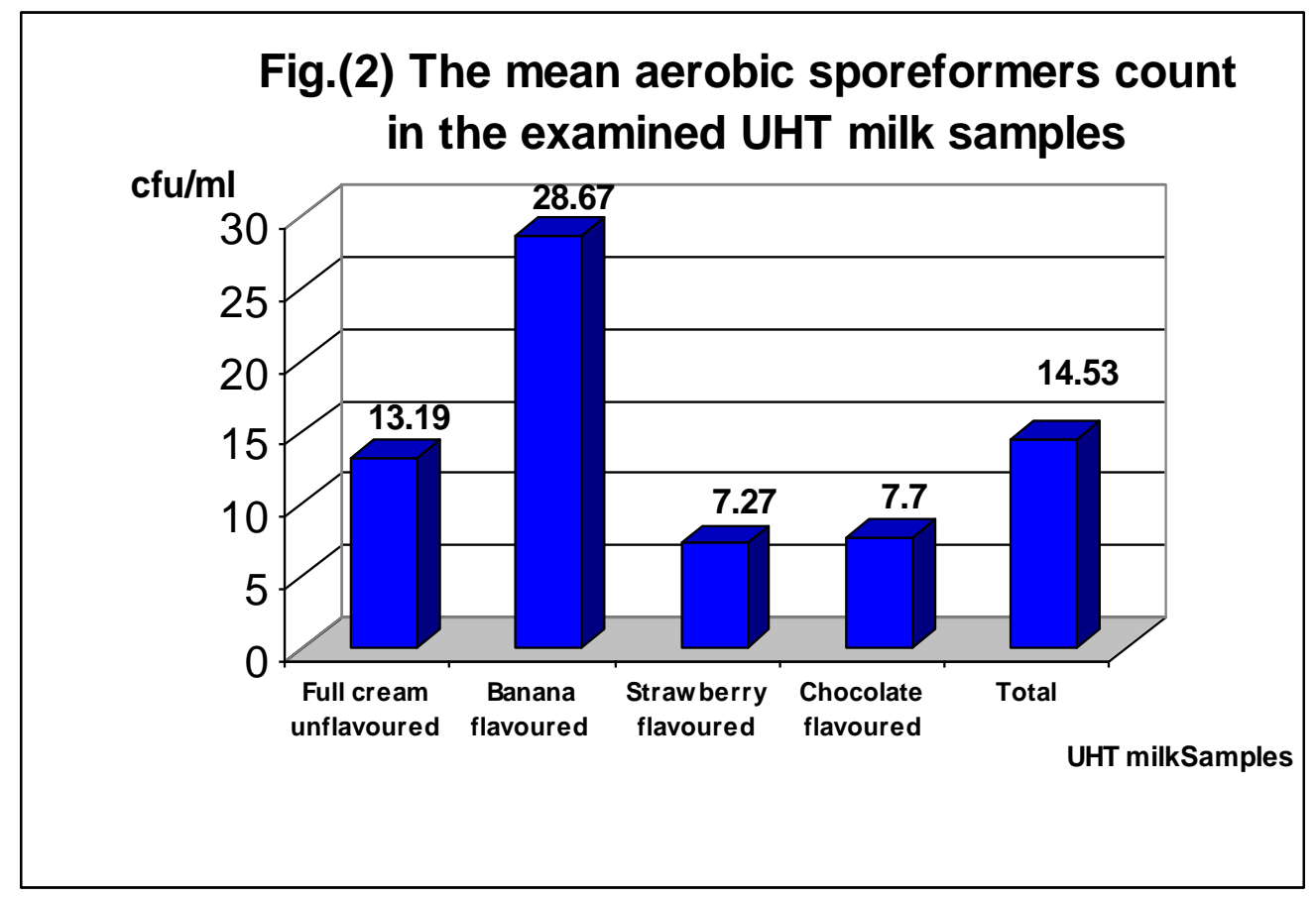




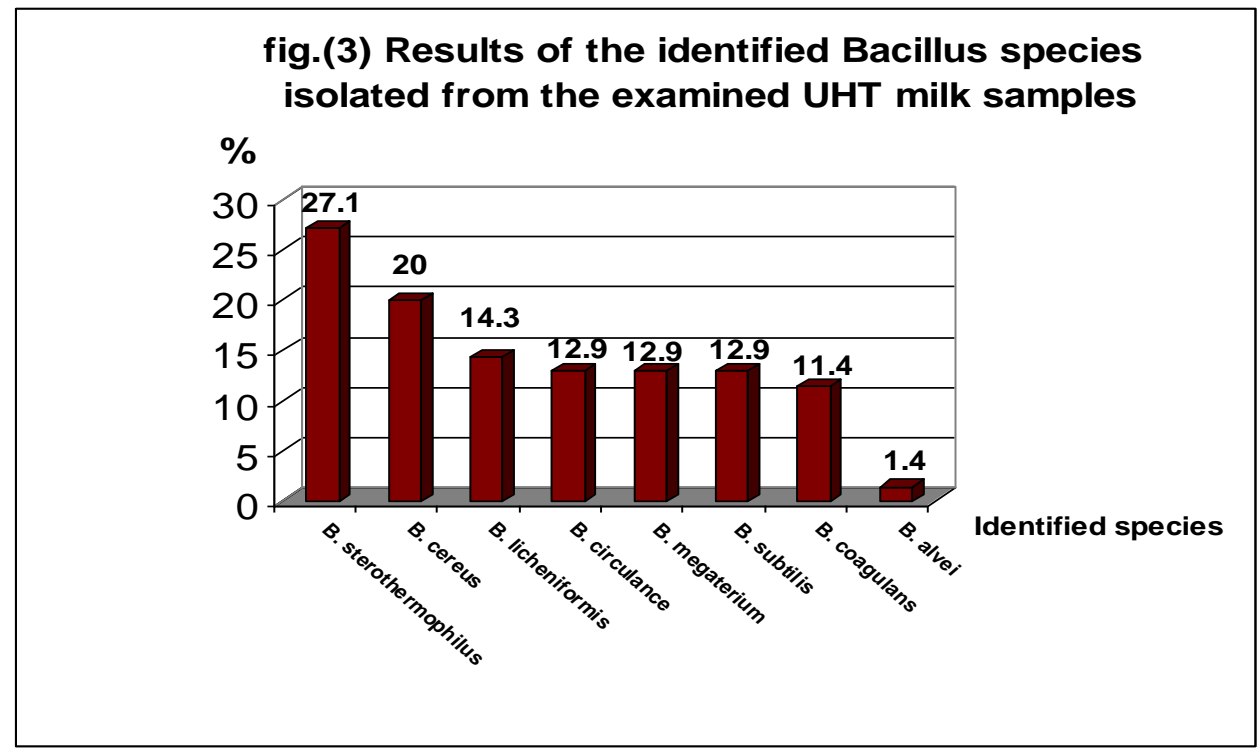

\section{DISCUSSION}

The results presented in Table 1 revealed that aerobic bacteria could be detected in $68.57 \%$ of the examined UHT milk samples after incubation at $30-35^{\circ} \mathrm{C}$ for 7 days $(80 \%, 53.3 \%, 66.67 \%$ and $66.67 \%$ of the examined unflavored full cream, banana flavored, strawberry flavored and chocolate flavored UHT milk samples respectively). The mean aerobic plate counts recorded for the previous samples were $10.4 \pm 9.6,27.5 \pm 39.4,19.6 \pm 27.9$ and $15.2 \pm 26.6 \mathrm{cfu} / \mathrm{ml}$, respectively (Table 1 and Fig. 1). Ezz El-Din (1999) recorded higher aerobic mesophilic count $\left(1.29 \times 10^{4} \mathrm{cfu} / \mathrm{ml}\right.$ as mean value) for 15 UHT milk samples.

The Egyptian standards (E.S) (2005) for long life sterilized milk reported that the total aerobic bacterial count should not exceed 10 $\mathrm{cfu} / \mathrm{ml}$ after incubation of milk at $30-35^{\circ} \mathrm{C}$ for 7 days. Table 1 showed that $16(22.9 \%)$ samples out of 70 UHT milk samples examined, exceeded the Egyptian standards; 6 (24\%) samples of unflavored full cream UHT milk, 3(20\%) samples of both banana and strawberry flavored UHT milk and 4(26.7\%) of chocolate flavored UHT milk samples.

Statistical analytical results of aerobic sporeformers count of the examined UHT milk samples revealed that, 49(70\%) of the total examined samples, 16(64\%) of unflavored full cream, 12(80\%) of banana flavored, $11(73.3 \%)$ of strawberry flavored and $10(66.67 \%)$ of 
chocolate flavored UHT milk samples examined were positive with mean counts of $13.19 \pm 28.7,28.67 \pm 44.1,7.27 \pm 4.3$ and $7.70 \pm 4.6$ $\mathrm{cfu} / \mathrm{ml}$, respectively (Table 2 and Fig. 2). Lower detection percentage (59.37\%) was reported by Schoken et al. (1996) in Brazil.

Results recorded in Table 3 declared that, the highest frequency $(59.19 \%)$ of positive UHT milk samples according to aerobic sporeformers count lies within the interval of $<10 \mathrm{cfu} / \mathrm{ml}$, followed by $32.65 \%$ of samples within the interval of $10:<20 \mathrm{cfu} / \mathrm{ml}$, while only $2(4.08 \%)$ samples had spore count $>100 \mathrm{cfu} / \mathrm{ml}$.

Bahout (2000) detected Bacillus spp. from only $18.3 \%$ of the examined (60) samples but with higher mean count $\left(2.6 \times 10^{2} \mathrm{cfu} / \mathrm{ml}\right)$ and the highest frequency distribution (63.63\%) lies within the range of $10^{2}: 10^{3}$. Also, Cosentino et al. (1997) recorded Bacillus spp. in $30 \%$ of the examined UHT milk with count ranged from $<10$ to $1200 \mathrm{cfu} / \mathrm{ml}$. and Schoken et. al. (1996) detected Bacillus spp. in 19(59.37\%) of 32 long life milk samples, of which 2 samples contained $>100 \mathrm{cfu} / \mathrm{ml}$.

The most frequent isolated Bacillus species was B.stearothermophilus that isolated from 19(27.1\%) of the examined samples. It is very heat resistant thermophilic strain that causes flavor spoilage (Lewis, 1999). The other species that could be isolated were B. cereus, B. Licheniforms, B. circulans, B. megaterium , B. subtilis, $B$. coagulans and $B$. alvei that could be isolated from 14(20\%), 10 (14.3\%), 9(12.9\%), 9(12.9\%), 9(12.9\%), $8(11.4 \%)$ and $1(1.4 \%)$ of the examined samples respectively (Table 4 and Fig. 3 ). The same species were identified by Aly, 1992; El-Shennawi, 1995; Cosentino et al., 1997; Bahout, 2000; Mayr et al., 2004 and Al-Leboudy et al., 2007 at different percentages.

These bacteria can contaminate milk supplies from water, udder, teat surfaces or from feed, dust and soil (Huang et al., 1999 and Scheldeman et al., 2002). Moreover, milking equipment can act as reservoirs for the spores into raw milk (Scheldeman et al., 2005). Furthermore, Bacillus species endospores can survive UHT milk production process (Huang et al., 1999; Vyletelova et al., 2002).

The main concern about the presence of these species in milk is not only the production of flavor defects by the action of proteolytic, lipolytic and phospholipase enzymes, but also they represent a public health hazard, as B. cereus that is responsible for two form of human gastroenteritis (Meer et al., 1991; Rangasamy et al., 1993). 
In conclusion it is suggested that the quality of UHT market milk could be improved by paying more attention to the quality of raw milk and to high standards of plant hygiene to avoid post-processing contamination. In addition, the dairy industry needs a simple rapid, sensitive, reliable and economical method for assessing the presence of heat resistant spores or their enzymes in milk.

\section{REFERENCES}

A.P.H.A "American public health association" (1992): Standards methods for the examination of dairy products, $16^{\text {th }}$ Ed., Washington, D.C.

Al-Leboudy, Ahlam, A.; Bkheet, A.A.; Amre, A.A.; Ewina, A.M. and ElAsiuty, M.S. (2007): Quality assurance procedures of ultra heat treated milk at local markets. $5^{\text {th }}$ Int. Sci. Conf., Mansoura, April 2007, P. 45-71.

Aly, Salwa, A.M. (1992): Studies on aerobic spore formers in raw and heat treated milks. M.V. Sc. Thesis Cairo Univ. Giza, Fac. of Vet. Med.

Aman, I.M.; Hahn, G. and Heeschen (1998): Bacillus cereus: its incidence in some Egyptian dairy products and its sensitivity towards nisin in reconstituted milk powder. $4^{\text {th }}$ World congress. Food Infection and Intoxication 7-12 June, Berlin, Germany. Vol. 11, 971-977.

Andersson, A.; Ronner, U. and Granum, P.F. (1995): What problems does the food industry have with the spore-forming pathogens Bacillus cereus and clostridium perfringens. Int. J. Food Microbiol. 28(2): 145-155.

Bahout, A.A. (2000): Prevalence of Bacillus species in UHT milk. Assiut Vet. Med. J. 42(84): 47-53.

Cosentino, S.; Mulargia, A.F.; Pisano, B.; Tuveri, P. and Palmas, F. (1997): Incidence and Biochemical characteristics of Bacillus flora in Sardinian dairy products. Int. J. Food Microbiol. 38(2/3): 235-238.

De Buyser, M.L.; Dufour, B.; Maire, M. and Lafarge V. (2001): Implication of milk and milk products in food borne diseases in France and in different industrialized countries. Int. J. Food Microbiol. 67(1-2): 1-17. 
Egyptian Standards (2005): ES: 1623-2005 long life sterilized milk. ICS: 67 100-10 Arab Republic of Egypt. Egyptian Organization for Standardization and Quality.

El-Shennawi, Saadeya, H.; Abou-Zaid, A. and Halawa, M. (1995): Occurrence of thermoduric microorganisms in UHT milk. Zagazig Vet. J. 23(1): 49-51.

Ezz-El-Din, Z.M. (1999): Microbial contamination of ultra heat treated (UHT) milk marketed at Domiat city, Egypt. Zagazig Vet. J., 27(2): 154-159.

Foschino, R.; Galli, A. and Ottogali, G. (1990): Research on the microflora of UHT milk. Ann. Microbiol. 40: 47-59.

Hammer, P.; Lembke, F.; Surhren, G. and Heeschen, W. (1995): Characterization of heat resistant mesophilic Bacillus species affecting quality of UHT milk - a preliminary report KielerMichwritchaftschaftliche- Forschungsberichte; 47(4): 297-305.

Hasan, A.N. (1990): Spore formers in milk. M. Sc. Thesis, Menia Univ. Fac. of Agric.

Holbrook, R. and Anderson, J.M. (1980): An improved selective and diagnostic medium for enumeration of Bacillus cereus in foods. Can. J. Microbiol. 26: 753-759.

Huang, C.C.; Lai, S.H.; Shih, S.L.; Liau, S.M. and Peng, J.S. (1999): A study on the spoilage of aseptic packaged long life milk caused by Bacillus cereus. J. of the Chinese Soc. of Animal Sci. 28(2): 249-259.

Krieg, N.R. and Holt, J.G. (1984): Bergy's Manual of Systematic Bacteriology. The Williams and wilkins, Baltimore/ London.

Lewis, M.J. (1999): Microbiological issues associated with heat treated milks. Int. J. of Dairy Tech. 52 (4): 121-125.

Mayr, R.; Gutser, K.; Busse, M. and Seiler, H. (2004): Indigenous aerobic sporeformers in high heat treated $\left(127^{\circ} \mathrm{C}, 5 \mathrm{~S}\right)$ German ESL (extended shelf life) milk. Milchwissenschaft, 59(314):143-146, Kempten, Germany.

Meer, R.R.; Baker, J.; Bodyfelt, F.W. and Griffiths, M.W. (1991): Psychrotrophic Bacillus spp. in fluid milk products: A review. J. Food Protec. 54(12): 969-979.

Ombui, J.N.; Naduhi, J.G. and Gicheru, M.M. (2008): Direct detection of Bacillus cereus enterotoxin genes in food by multiplex polymerase chain reaction. Int. J. of Integrative Bio. 2(3): $172-181$. 
Oxoid (1980): Manual of Culture Media Ingredients and Other Laboratory Services $4^{\text {th }}$ Ed. Published by OXOID limited, Wade Road, Basingstoke Hampshire RG 24 OPW.

Rangasamy, P.N.; Lyer, M. and Roginski, H. (1993): Isolation and characterization of Bacillus cereus in milk and dairy products manufactured in Victoria. The Aust. J. of Dairy Techn., 48: 93-95.

Scheldeman, P.; Herman, L.; Goris, J.; Vos, P. de and Heyndrickx, M. (2002): Polymerase chain reaction identification of Bacillus sporothermodurans from dairy sources. J.of Appl. Microbiol. 92(5): 983-991.

Scheldeman, P.; Pil, A.; Herman, L.; Vos, P. de and Heyndrickx, M. (2005): Incidence and diversity of potentially highly heat resistant spores isolated at dairy farms. Appl. and Environ. Microbiol. J. 71(3): 1480- 1494.

Schoken, I.RP.; Nader, F.A.; Dimenstein, A.R.; Palbo-Schoken, I.R. and Ricardo, D.A. (1996): Incidence of spore-forming Bacillus and Clostridium in samples of long life milk. Higiene-Alimentar 10:42, 25-27.

Taher, Zainab, M.A. (2004): Studies on Bacillus cereus and related species in heat-treated milk and some milk products. M.V.Sc. Thesis, Assiut Univ. Fac. of Vet. Med.

Varnam, A.H. and Sutherland, J.P. (1994): Milk and Milk products, Technology, Chemistry and Microbiology. $1^{\text {st }}$ Ed.1994, Chapter 2.

Vyetelova, M.; Svec, P.; Pacova, Z.; Sedlacek, I. and Roubal, P. (2002): Occurrence of Bacillus cereus and Bacillus licheniformis strains in the course of UHT milk production. Zech- J. of Animal Sci., 47(5): 200-205. 